\title{
MICROHARDNESS DIFFERENCES BETWEEN SILK FIBER AS A NATURAL FILLER COMPOSITE RESIN WITH NANOFILLER COMPOSITE RESIN
}

Sartika Puspita*, Romadhon Yuan Aziz**, Dwi Aji Nugroho***

*Departemen Oral Biologi, Program Studi Kedokteran Gigi, Universitas Muhammadiyah Yogyakarta

${ }^{* *}$ Rumah Sakit Gigi dan Mulut, Universitas Muhammadiyah Yogyakarta

${ }^{* * \star D}$ Departemen Dental Material, Program Studi Kedokteran Gigi, Universitas Muhammadiyah Yogyakarta

Correspondence : Sartika Puspita, Departemen Oral Biologi, Program Studi Kedokteran Gigi, Universitas Muhammadiyah Yogyakarta

Email : sartika.puspita@umy.ac.id

\begin{tabular}{|c|}
\hline Keywords: \\
Bombyx mori L., \\
Composite Resin, \\
Microhardness, \\
Nanofiller, Natural Filler \\
Composite Resin \\
\hline
\end{tabular}

ABSTRACT

Background: Dental composite composed of natural filler is a trend nowadays. Silk fiber, Bombyx mori L., is one of the natural fibers that have good microhardness (66 VHN) and has a potency to become a renewable natural filler. This research aimed to determine microhardness differences of silk fiber composite B. mori L., and nanofiller composite resin as a gold standard.

Method: A quasi-experimental laboratory using composite resin with silk fiber B. mori L., as a natural filler; nanofiller composite Z350 XT flowable (3M ESPE, USA) as a positive control and no-filler composite as a negative control. Four cylindrical specimens per group were made $(d=3 \mathrm{~mm}, h=6 \mathrm{~mm})$. Microhardness tests were done with Vickers hardness tester (Shimadzu, Japan). Indentation of 100 grams for 20 seconds.

Result: There were significant differences in the natural filler, nanofiller group (positive) control and no-filler composite (negative control). Based on the Kruskal Wallis test result, there was a significant difference in microhardness $(p=0.024)$. The highest microhardness was nanofiller $(115,2 \mathrm{VHN})$, silk fiber filler (109,4 VHN), and no-filler composite (32,2 VHN).

Conclusion: Silk fiber Bombyx mori L., has shown the good potential of being a renewable natural filler $(109,4$ VHN) however lower than nanofiller composites.

\section{PENDAHULUAN}

Resin komposit sebagai bahan restorasi gigi memiliki banyak kelebihan diantaranya adalah estetika yaitu warna yang serupa dengan gigi sehingga menguntungkan pada restorasi gigi anterior. Sifat lainnya yaitu memiliki kekerasan yang cukup untuk menahan beban pengunyahan sehingga cocok untuk bahan restorasi gigi posterior. ${ }^{1}$ Resin komposit terdiri atas tiga bahan penyusun utama; yaitu monomer, filler, coupling agent. Ketiga bahan ini disempurnakan dengan penambahan bahan lainnya seperti akselerator- inisiator. ${ }^{2,3,4,5}$ Komponen filler pada umumnya berasal dari bahan inorganik seperti glass (kaca) dan silika. Bahan filler ditambahkan bahan lain untuk mendapatkan warna radiopak. Bahan-bahan tersebut diantaranya barium, boron, zink dan senyawa logam lainnya. 2,5

Klasifikasi resin komposit pada umumnya dibagi berdasarkan ukuran filler yang digunakan, sehingga dapat dibagi sebagai resin komposit macrofill, midfiller, minifiller, microfill, dan nanofill. Resin komposit yang berukuran nanofill memiliki 
sifat estetik yang tinggi. ${ }^{5}$ Namun bahan inorganik filler tersebut memiliki kekurangan yaitu tidak terbarukan.

Kekurangan filler inorganik dapat diatasi menggunakan bahan-bahan dari organik (alam). Keuntungan filler alam adalah bahan terbarukan. ${ }^{6}$ Penggunaan bahan alam pada filler komposit juga dapat menambah nilai jual dari bahan tersebut. Kriteria dari bahan alam yang dapat menggantikan filler inorganik yaitu harus memiliki kekerasan yang baik terhadap enamel dan dentin, yaitu berada pada kisaran 50 hingga $370 \mathrm{VHN}^{7}$

Serat alam memiliki kelebihan yang dibutuhkan untuk menjadi filler komposit yaitu kekuatannya yang baik dan merupakan bahan yang terbarukan. ${ }^{6}$ Bahan yang mungkin menjadi alternatif yaitu serat sutra yang dihasilkan oleh ulat sutra $B$. mori L., Resin dari serat sutra B. mori L., murni telah dibuktikan memiliki kekerasan yang cukup untuk menggantikan filler inorganik yaitu sebesar 66 VHN. ${ }^{8}$ Serat sutra dari B. mori L., sebelum digunakan sebagai filler terlebih dahulu dilakukan degumming untuk menghilangkan lapisan serisin lalu akan digiling sehingga menjadi partikel serat sutra yang lebih kecil (1-3 mm). ${ }^{8,9}$ Serisin merupakan lapisan lengket seperti lem yang membungkus bagian luar kokon ulat sutra $B$. mori L. ${ }^{9}$

Gigi merupakan organ yang memiliki kekuatan tekan cukup tinggi, sehingga apabila terjadi kerusakan atau kavitas, diharapkan adanya bahan tumpatan yang memiliki kekuatan tekan lebih baik dari dentin sehingga dapat mengembalikan fungsi gigi menjadi lebih optimal. ${ }^{10}$ Oleh karena itu, microhardness pada resin komposit dengan serat sutra $B$. mori L., sebagai filler organik, perlu diteliti kekuatan tekannya dibandingkan dengan dentin. Uji microhardness dalam penelitian ini diperlukan untuk mengetahui apakah serat sutra B. mori L., sebagai filler komposit memiliki kekuatan tekan cukup atau lebih baik dari dentin sebagai bahan restorasi.

\section{METODE PENELITIAN}

Desain Penelitian ini merupakan kuasi eksperimental laboratori. Protokol penelitian telah mendapatkan ijin dari Komite Etik Penelitian Fakultas Kedokteran dan IImu Kesehatan Universitas Muhammadiyah Yogyakarta, dengan No.007/EC-EXEM-KEPK FKIK UMY/IX/2019.

Penelitian ini menggunakan serat sutra $B$. mori L., sebagai filler alam yang sudah dilakukan proses degumming untuk menghilangkan lapisan serisin. Identifikasi filler serat sutra diamati menggunakan Scanning Electron Microscope (SEM) untuk memastikan lapisan serisin sudah hilang dan mengetahui dimensi ukuran filler (gambar 1). Selanjutnya serat sutra digiling menggunakan dry mill (Phillip, Japan) hingga menjadi potongan-potongan yang lebih kecil $(1-3$ $\mathrm{mm}$ ). ${ }^{8}$ Nanofiller Z350 XT flowable (3M ESPE, USA) sebagai kontrol positif. Matriks resin yang terdiri dari: Bis-GMA (Sigma-Aldrich, USA), TEGDMA (Sigma-Aldrich, USA), UDMA (SigmaAldrich, USA), Camphorquinone (Sigma-Aldrich, USA) digunakan sebagai bahan matriks resin komposit filler serat sutra dan sebagai kontrol negatif (komposit tanpa filler).

Sampel penelitian terdiri dari empat kelompok perlakuan. Kelompok pertama yaitu kelompok gold standar berupa nanofiller Z350 XT flowable. Kelompok kedua dan ketiga yaitu kelompok resin komposit dengan filler serat sutra dengan masing-masing volume $3 \%$ dan $63 \%$ (sesuai volume filler gold standar). Kelompok keempat yaitu kelompok kontrol berupa resin komposit tanpa filler. Pencampuran matriks resin 
monomer bis-GMA, TEGDMA, dan UDMA dengan filler serat sutra untuk menjadi resin komposit silk fiber filler dilakukan di Laboratorium Molecular Medicine and Therapy Universitas Muhammadiyah Yogyakarta.

Keempat kelompok perlakuan dicetak dengan tabung berukuran diameter $3 \mathrm{~mm}$ dan tinggi $6 \mathrm{~mm}$ kemudian dilakukan uji microhardness menggunakan Vickers microhardness tester (Shimidzu, Japan).

Data microhardness keempat kelompok dilakukan uji beda antar kelompok. Sebelum dilakukan uji beda, data diuji normalitas dan homogenitasnya terlebih dahulu menggunakan Saphiro Wilk dan uji Levene. Apabila data berdistribusi normal dan homogen, dapat dilanjutkan uji beda menggunakan uji One-way ANOVA. Namun apabila data tidak berdistribusi normal dan homogen, maka dilakukan uji KruskallWallis dan uji Post-hoc Mann-Whitney U.

\section{HASIL PENELITIAN}

Serat sutra B. mori L., sebagai bahan filler resin komposit setelah dilakukan degumming diamati menggunakan scanning electro microscope (SEM) perbesaran 1000 dan 5000 kali dapat dilihat pada gambar 1a dan 1b. Serat sutra diketahui memiliki dimensi ukuran lebar 8 - 17,145 $\mu \mathrm{m}$.

Perbedaan microhardness dari keempat perlakuan dan setiap kelompok dianalisis besar perbedaan pengukuran menggunakan uji statistik yaitu perhitungan selisih. Dan nilai microhardness setiap spesimen sampel dapat dilihat pada tabel 1 . Semakin tinggi nilai microhardness maka kekerasan spesimen tersebut semakin baik. Sebaliknya apabila microhardness semakin rendah menunjukkan kekerasan spesimen yang kurang baik. Tabel 1 menunjukkan kelompok perlakuan 2 dan kelompok kontrol positif memiliki selisih rata-rata microhardness yang rendah $(5,8$ VHN). Volume filler serat sutra kelompok 2 memiliki volume sama dengan kelompok kontrol positif yaitu $63 \%$. Rata-rata microhardness resin komposit kelompok 1 terhadap kontrol negatif (resin komposit tanpa filler) memiliki selisih microhardness yang rendah (13,3 VHN) dikarenakan volume filler kelompok 1 hanya $3 \%$. Sehingga tidak sebanding dengan kontrol positif (komposit nanofiller).

Berdasarkan penelitian ini menunjukkan bahwa resin komposit tanpa filler memiliki kekerasan yang kurang baik dibandingkan resin komposit dengan nanofiller (Tabel 1). Filler komposit alam serat sutra dengan volume yang sama dengan nanofiller (63\%) mampu mendekati kontrol positif dalam hal sifat kekerasan fisiknya.

Untuk mengetahui apakah terdapat perbedaan bermakna antara keempat sampel kelompok tersebut maka dilakukan pengujian statistik menggunakan Kruskal Wallis Test.

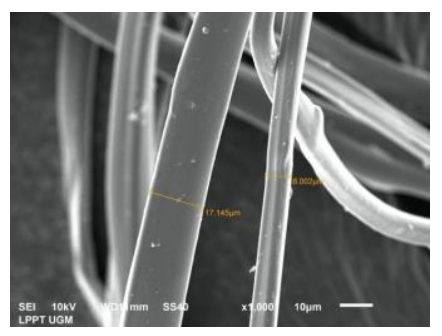

(a)

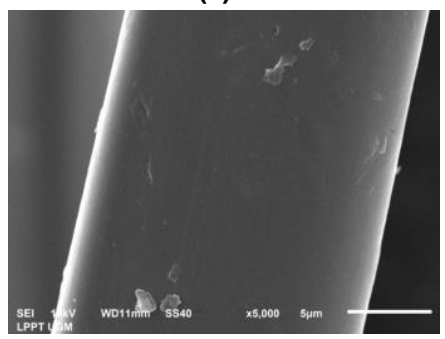

(b)

Gambar 1. Serat sutra B. mori L., sebagai filler alam resin komposit, dilihat menggunakan Scanning Electron Microscope (SEM) dengan perbesaran (a) 1000 kali dan (b) 5000 kali memiliki lebar serat $8-17,145 \mu \mathrm{m}$. 
Tabel 1. Hasil uji Vickers microhardness (Shimadzu, Japan) pada kelompok spesimen penelitian.

\begin{tabular}{ccc}
\hline Spesimen & Microhardness (VHN) & Rata-rata Microhardness (VHN) \\
\hline & 32,7 & 32,2 \\
Resin Komposit tanpa filler (kontrol & 33,3 & \\
negatif) & 32 & \\
& 31 & 45,5 \\
Resin komposit filler serat sutra & 45,3 & \\
Bombyx mori L. 3\% (kelompok & 45 & \\
perlakuan 1) & 44 & 109,4 \\
\hline Resin komposit filler serat sutra & 47,7 & \\
Bombyx mori L. 63,3\% (kelompok & 191,7 & 115,2 \\
perlakuan 2) & 75,8 & \\
\hline
\end{tabular}

Hasil uji normalitas menggunakan Shapiro-Wilk menunjukkan bahwa dari keempat kelompok memiliki distribusi $p>0,05$ sehingga semua data memiliki distribusi normal. Hasil uji homogenitas (Tabel 3) menunjukkan $p=0,000$ $(p<0,05)$ sehingga variansi dari data tersebut tidak homogen. Oleh karena itu, uji perbandingan ratarata One-Way ANOVA tidak dapat digunakan. Alternatif uji One-Way ANOVA apabila syarat tidak terpenuhi adalah uji non-parametrik Kruskal Wallis.
Hasil uji pada tabel 2 menunjukkan nilai signifikansi sebesar $p=0,024 \quad(p<0,05)$ sehingga hasil tersebut menunjukkan bahwa terdapat perbedaan yang bermakna antara keempat kelompok perlakuan. Selanjutnya, untuk mengetahui letak perbedaan bermakna antar kelompok dapat diketahui dengan melanjutkan uji Mann-Whitney antara masing-masing kelompok perlakuan, angka yang diambil adalah dari tabel Asymp. Sig. (2-Tailed)

Tabel 2. Hasil uji non-parametrik Kruskall Wallis antar kelompok.

\begin{tabular}{cc}
\hline & Microhardness \\
\hline Kruskal-Wallis H & 9,441 \\
\hline$d f$ & 3 \\
\hline Asymp. Sig. & $0,024^{*}$ \\
\hline
\end{tabular}

Keterangan: $\left(^{*}\right)=p<0.05$ (terdapat perbedaan yang bermakna antara keempat kelompok penelitian).

Selanjutnya dikarenakan terdapat perbedaan yang signifikan antar kelompok maka dilanjutkan uji post hoc Mann Whitney untuk mengetahui kelompok berapa saja yang terdapat perbedaan. Hasil ringkasan uji Mann Whitney dapat dilihat pada tabel berikut: 
Tabel 3. Hasil uji Mann-Whitney antar 4 kelompok sampel.

\begin{tabular}{|c|c|c|c|c|}
\hline Perlakuan & Kontrol Negatif & $\begin{array}{c}\text { Kelompok } \\
\text { Perlakuan } 1\end{array}$ & Kontrol Positif & $\begin{array}{c}\text { Kelompok } \\
\text { Perlakuan } 2\end{array}$ \\
\hline $\begin{array}{l}\text { Kontrol Negatif } \\
\text { (resin komposit } \\
\text { tanpa filler) }\end{array}$ & & $0.021^{*}$ & $0.021^{*}$ & 0.083 \\
\hline $\begin{array}{c}\text { Kelompok } \\
\text { Perlakuan } 1 \\
\text { (Resin komposit } \\
\text { filler serat sutra } \\
\text { Bombyx mori L. } \\
3 \% \text { ) }\end{array}$ & $0.021^{*}$ & & $0.021^{*}$ & 0.248 \\
\hline $\begin{array}{c}\text { Kontrol Positif } \\
\text { (Resin komposit } \\
\text { Z350 XT Flowable) }\end{array}$ & $0.021^{*}$ & $0.021^{*}$ & & 1.000 \\
\hline $\begin{array}{c}\text { Kelompok } \\
\text { Perlakuan } 2 \\
\text { (Resin komposit } \\
\text { filler serat sutra } \\
\text { Bombyx mori L. } \\
63,3 \% \text { ) }\end{array}$ & 0.083 & 0.248 & 1.000 & \\
\hline
\end{tabular}

Keterangan: $\left(^{*}\right)=p<0.05$ (terdapat perbedaan yang bermakna)

Hasil uji Mann-Whitney (Tabel 3) menunjukkan bahwa kelompok perlakuan 1 terhadap kontrol positif dan negatif memiliki perbedaan yang bermakna $(p<0,05)$. Kelompok perlakuan 2, resin komposit filler serat sutra B. mori L., 63,3\%, tidak memiliki perbedaan yang bermakna terhadap kontrol negatif, kelompok perlakuan 1 maupun kontrol positif. Hal ini akan dilakukan pembahasan pada diskusi.

\section{DISKUSI}

Hasil penelitian perbedaan microhardness resin komposit filler serat sutra menunjukkan ratarata 32,2 VHN; 45,5 VHN; 109,4 VHN dan 115,2 VHN pada kelompok kontrol negatif, kelompok perlakuan 1, kelompok perlakuan 2 dan kelompok kontrol positif secara berurutan. Secara statistik perbedaan tersebut dapat dikatakan sebagai perbedaan yang bermakna. Perbedaan dari kelompok kontrol negatif dengan kelompok perlakuan 1 dan kelompok kontrol positif dikarenakan penambahan filler. Penambahan filler akan memperbaiki sifat mekanis dari suatu bahan, salah satunya yaitu kekerasan dari bahan tersebut. 2,3,4 Perbedaan tersebut bisa dilihat dari hasil pengukuran microhardness yang ada. Kelompok tanpa filler hanya mendapatkan rata-rata hasil 32,2 VHN, sedangkan kelompok dengan filler mendapatkan hasil yang lebih baik yaitu 45,5 VHN dan 115,2 VHN. Dengan peningkatan rata-rata kekerasan 13,3 VHN dan 83 VHN secara berurutan.

Perbedaan yang bermakna antara microhardness kontrol positif dibandingkan dengan kelompok perlakuan 1 didapatkan karena selisih yang cukup jauh dari kekerasan filler pengisi yang ada. Z350 XT memiliki filler kuarsa, ${ }^{11}$ sedangkan resin komposit filler serat alam memiliki filler silk fibre dan pengurangan kekerasan pada silk fibre terjadi karena proses degumming yang menghilangkan lapisan serisin. Melemahnya satu jenis interaksi nonkovalen dari inti serat sutra fibroin, seperti ikatan hidrogen dan ikatan Van der 
waals akibat dari proses degumming. ${ }^{12}$ Berdasarkan hasil penelitian ini, permasalahan pengurangan kekerasan filler serat sutra oleh karena kehilangan serisin dapat diatasi dengan penyesuaian pada persentase volume filler yaitu disamakan dengan kontrol positif (Tabel 1). Terbukti dengan penambahan filler serat sutra pada kelompok perlakuan 2 yaitu sebanyak $63 \%$. Hasil pengukuran microhardness dari kelompok perlakuan 2 memiliki nilai kekerasan paling tinggi 191,7 VHN, sedangkan nilai maksimal pada kelompok kontrol positif di angka 119,7 VHN (Tabel 1). Hasil penelitian ini menunjukkan potensi yang baik dari bahan serat sutra Bombyx mori $\mathrm{L}$ sebagai filler komposit. kekurangan lainnya yang dapat diminimalisir adalah pada tingkat kelembapan filler dan juga pada masalah porositas. ${ }^{9}$

Serat sutra B. mori L., memiliki karakteristik mudah menyerap air. B. mori L., film dapat menyerap kelembapan hingga $20-23 \%$ berat pada kelembapan $75 \% .{ }^{13} \mathrm{Hal}$ tersebut terjadi karena pada serat $B$. mori $L$., terdapat serat dengan gugus hidrofilik. Kadar air pada filler dapat merusak hubungan matriks dan filler. Penelitian kali ini menggunakan serat sutra $B$. mori L., yang masih berbentuk untaian-untaian serat. Serat sutra yang lembab dan berbentuk untaian dapat menyebabkan porus. $^{9}$

Porositas adalah keadaan dimana terdapat butiran udara di dalam campuran polimer. Hal tersebut bisa terjadi akibat dari proses pengadukan dan reaksi kimia. Hal tersebut juga memengaruhi kekerasan suatu bahan. Terlebih ketika pengadukan dan pencampuran bahan dilakukan secara manual. Pada setiap persen porusitas menurunkan sifat mekanis komposit dalam hal ini ketahanan fraktur sebanyak $7 \% .{ }^{14}$ Porus yang minimal sangat dibutuhkan dalam sebuah komposit, karena pada umumnya porositas memiliki pengaruh yang besar terhadap kekuatan mekanis komposit. ${ }^{15}$

Persebaran filler yang homogen pada bahan restorasi komposit sangat penting dalam proses pengukuran microhardness dikarenakan sebaran filler yang homogen tersebut sangat penting terkait teknik pengukuran kekerasan sampel yang menggunakan jejak mikro yang sangat kecil (satuan $\mu \mathrm{m}) .{ }^{16}$ Kelemahan penelitian ini adalah homogenitas filler serat sutra terhadap matriks resin karena dimensi ukuran filler serat sutra berbentuk serat sehingga filler serat sutra sulit tercampur secara homogen dengan matriks resin. Berdasarkan hasil pengukuran kekerasan sampel terdapat rentang yang besar antar sampel kelompok perlakuan 2 yaitu 159,2 VHN (Tabel 1), dimana nilai maksimum di angka 191,7 VHN dan nilai minimum di angka 32,5 VHN. Nilai maksimum ini menunjukkan bahwa jejak pengukuran alat vickers hardness mengenai daerah campuran matriks dan filler sehingga didapatkan angka microhardness besar. Sedangkan angka 32,5 VHN mendekati angka kelompok kontrol negatif (resin komposit tanpa filler). Angka tersebut kemungkinan jejak pengukuran alat vickers hardnes mengenai daerah tanpa filler sehingga mendapatkan angka microhardness kecil (32,5 VHN) (Tabel 1). ${ }^{8}$

Kelemahan penelitian ini adalah tidak terjadinya homogenitas filler pada resin komposit silk fiber filler. Ketidak homogenitas ini dapat terjadi karena pada saat pencampuran dengan matriks resin. Filler yang berbentuk serat sulit tercampur dengan pencampuran manual, sehingga untuk penelitian yang akan datang diperlukan alat mixer pencampur matriks resin dengan serat sutra ataupun serat alam yang lain. Solusi yang lain adalah dengan membentuk serat sutra menjadi ukuran yang lebih kecil yaitu nanometer sehingga 
lebih mudah dilakukan pencampuran dengan matriks resin saat pembuatan resin komposit serat alam.

\section{KESIMPULAN}

Berdasarkan hasil penelitian perbedaan microhardness antara resin komposit filler serat sutra B. mori L., dengan resin komposit nanofiller disimpulkan bahwa: Nanofiller komposit memiliki microhardness paling tinggi 115,2 VHN. Resin komposit filler serat sutra memiliki potensi yang baik sebagai bahan filler organik terbarukan yang dapat menggantikan bahan filler anorganik kuarsa $(109,4$ VHN).

\section{DAFTAR PUSTAKA}

1. Nugroho DA, Widjijono, Nuryono, Asmara W, Wajar D. Efek Jumlah Kandungan Filler Nanosisal Terhadap Ketahanan Fraktur Resin Komposit. Insisiva Dental Journal. 2017; 6(1):17-23.

2. Anusavice KJ, Shen C, Rawls HR. Phillips' Science of Dental Materials. 12th ed. Saunders; 2012. 592.

3. Noort $\mathrm{R}$ van. Introduction to dental materials. 4th ed. Edinburgh; New York: Mosby Elsevier; 2013. 246.

4. Randolph LD, Palin WM, Leloup G, Leprince JG. Filler characteristics of modern dental resin composites and their influence on physico-mechanical properties. Dent Mater. 2016; 32(12):1586-1599.

5. Sakaguchi RL, Ferracane JL, Powers JM, editors. Craig's restorative dental materials. Fourteenth edition. St. Louis, Missouri: Elsevier; 2019.

6. Kumar Gupta G, De S, Franco A, Balu A, Luque R. Sustainable Biomaterials: Current
Trends, Challenges and Applications. Molecules. 2015; 21(1):48.

7. Shakila N, Ali A, Zaidi S. Micro Hardness of Dental Tissues Influenced by Administration of Aspirin During Pregnancy. Int J Morphol. 2015; 33(2):586-593.

8. Tuan HA, Hirai S, Tamada Y, Akioka S. Preparation of silk resins by hot pressing Bombyx mori and Eri silk powders. Mater Sci Eng C. 2019; 97:431-437.

9. Vepari C, Kaplan DL. Silk as a biomaterial. Prog Polym Sci. 2007; 32(8-9):991-1007.

10. Miletic V, editor. Dental Composite Materials for Direct Restorations. Cham:Springer International Publishing; 2018

11. Vskd A, Fayhin SH, Askik SH. Filtek Z350 XT Technical Product Profile - 3M. Filtek Z350 XT Technical Product Profile - 3M. 2010

12. Jiang $\mathrm{P}$, Liu $\mathrm{H}$, Wang $\mathrm{C}$, Wu L, Huang J, Guo C. Tensile behavior and morphology of differently degummed silkworm (Bombyx mori) cocoon silk fibres. Mater Lett. 2006; 60(7):919-925.

13. Amrita S, Connor AJ, Kofas M, Zha RH. Chemical Synthesis of Sllk Mimetic Polymers. Materials (Basel). 2019; 12(4086):1-24.

14. Kastner J, Plank B, Salaberger D, Sekelja J. Defect and Porosity Determination of Fibre Reinforced Polymers by X-ray Computed Tomography. 2nd International Symposium on NDT in Aerospace 2010 - We.1.A.2. 2010; 1 -12.

15. Pickering KL, Efendy MGA, Le TM. A review of recent developments in natural fibre composites and their mechanical performance. Compos Part Appl Sci Manuf. 2016; 83:98-112.

16. Bhusan, B. Depth-sensing nanoindentation measurement techniques and applications. Microsystem Technologies. 2017; 23:15971649 